\title{
Correction to: Opioid-free versus opioid- based anesthesia in pancreatic surgery
}

Stéphane Hublet ${ }^{1}$, Marianne Galland ${ }^{1}$, Julie Navez ${ }^{2}$, Patrizia Loi $^{2}$, Jean Closset ${ }^{2}$, Patrice Forget ${ }^{3}$ and Pierre Lafère ${ }^{1 *}$

\section{Correction to: BMC Anesthesiol 22, 9 (2022) https://doi.org/10.1186/s12871-021-01551-y \\ Following publication of the original article [1], the authors reported an error in the presentation of the names wherein the given and last names has been swapped. The correct presentations are as follows:}

Given name: Stéphane, Last name: Hublet

Given name: Marianne, Last name: Galland

Given name: Julie, Last name: Navez

Given name: Patrizia, Last name: Loi

Given name: Jean, Last name: Closset

Given name: Patrice, Last name: Forget

Given name: Pierre, Last name: Lafère

The original article [1] has been updated.

\author{
Reference \\ 1. Hublet S, Galland M, Navez J, et al. Opioid-free versus opioid-based anes- \\ thesia in pancreatic surgery. BMC Anesthesiol. 2022;22:9. https://doi.org/ \\ 10.1186/s12871-021-01551-y.
}

\begin{abstract}
Author details
'Department of Anesthesiology, Université Libre de Bruxelles, CUB Érasme, Brussels, Belgium. ${ }^{2}$ Department of Abdominal Surgery and Transplantation, Université Libre de Bruxelles, CUB Érasme, Brussels, Belgium. ${ }^{3}$ Clinical Chair in Anaesthesia, University of Aberdeen, Aberdeen, UK.
\end{abstract}

Published online: 22 January 2022
The original article can be found online at https://doi.org/10.1186/s12871021-01551-y.

*Correspondence: doc.lafere@proximus.be

${ }^{1}$ Department of Anesthesiology, Université Libre de Bruxelles, CUB Érasme, Brussels, Belgium

Full list of author information is available at the end of the article

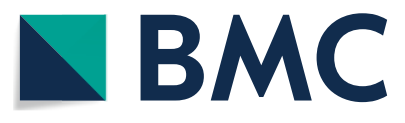

(c) The Author(s) 2022. Open Access This article is licensed under a Creative Commons Attribution 4.0 International License, which permits use, sharing, adaptation, distribution and reproduction in any medium or format, as long as you give appropriate credit to the original author(s) and the source, provide a link to the Creative Commons licence, and indicate if changes were made. The images or other third party material in this article are included in the article's Creative Commons licence, unless indicated otherwise in a credit line to the material. If material is not included in the article's Creative Commons licence and your intended use is not permitted by statutory regulation or exceeds the permitted use, you will need to obtain permission directly from the copyright holder. To view a copy of this licence, visit http://creativecommons.org/licenses/by/4.0/. The Creative Commons Public Domain Dedication waiver (http://creativeco mmons.org/publicdomain/zero/1.0/) applies to the data made available in this article, unless otherwise stated in a credit line to the data. 